\title{
Tetanic Contraction
}

National Cancer Institute

\section{Source}

National Cancer Institute. Tetanic Contraction. NCI Thesaurus. Code C113493.

A single uterine contraction lasting greater than 2 minutes. 